\title{
Comparison of prosodic characteristics by question type in left- and right-hemisphere-injured stroke patients*
}

\author{
Youngmi $\mathrm{Yu}^{1} \cdot$ Cheoljae Seong ${ }^{2, * *}$ \\ ${ }^{1}$ Speech-Language Pathology, Chungnam National University, Daejeon, Korea \\ ${ }^{2}$ Linguistics, Chungnam National University, Daejeon, Korea
}

\begin{abstract}
This study examined the characteristics of linguistic prosody in terms of cerebral lateralization in three groups of 9 healthy speakers and 14 speakers with a history of stroke (7 with left hemisphere damage (LHD), 7 with right hemisphere damage (RHD)). Specifically, prosodic characteristics related to speech rate, duration, pitch, and intensity were examined in three types of interrogative sentences (wh-questions, yes-no questions, alternative questions) with auditory perceptual evaluation. As a result, the statistically significant key variables showed flaws in production of the linguistic prosody in the speakers with LHD. The statistically significant variables were more insufficiently produced for wh-questions than for yes-no and alternative questions. This trend was particularly noticeable in variables related to pitch and speech rate. This result suggests that when Korean speakers process linguistic prosody, such as that of lexico-semantic and syntactic information in interrogative sentences, the left hemisphere seems to be superior to the right hemisphere.
\end{abstract}

Keywords: strokes, linguistic prosody, interrogative sentences, acoustic analysis, auditory perceptual experiment

\section{1. 서론}

정확한 의사소통을 하기 위해서는 분절음 정보(segmental information)뿐만 아니라 초분절음 정보(suprasegmental information)의 정확한 산출도 중요하다. 운율(prosody)은 초분절음 정보로서음 도(pitch), 강도(intensity), 지속시간(duration)과 같은 음향 단서 를 사용한다(Witteman et al., 2011).

운율은 기능에 따라 언어적 운율(linguistic prosody)과, 정서적 운율(affective prosody)로 분류할 수 있다(Myers, 1999). 언어적 운율은 의문사 또는 평서문 등의 문법정보를 음향적 단서를 통 해 전달함으로써 의미를 명확히 하고 문장의 모호성을 해결하 며, 정서적 운율은 화자의 감정 상태(화남, 슬픔, 기쁨 등)와 같 은 부차적 정보(paralinguistic information)를 전달한다.

대부분의 연구는 정서적 운율처리에 있어 우반구가 우세하 다는 주장이 많다(Blonder et al., 1991; Bowers et al., 1987; Ehlers \& Dalby, 1987; Heilman et al., 1975; Heilman et al., 1984; Ross,

\footnotetext{
* This paper is revised and supplemented from some part of the first author's 2020 Master's thesis (Yu, 2020) and Proceedings of the 2020 Conference of the Korean Society of Speech Sciences (Yu et al., 2020).

** cjseong49@gmail.com, Corresponding author Received 2 July 2021; Revised 12 August 2021; Accepted 13 August 2021

(c) Copyright 2021 Korean Society of Speech Sciences. This is an Open-Access article distributed under the terms of the Creative Commons Attribution NonCommercial License (http://creativecommons.org/licenses/by-nc/4.0) which permits unrestricted non-commercial use, distribution, and reproduction in any medium, provided the original work is properly cited.
} 
1981; Tucker et al., 1977). 하지만 언어적 운율 처리에 있어서는 상대적으로 의견일치가 잘 되지 않고 있다. 언어적 운율처리에 관련된 연구들은 1) 우반구 손상 환자는 언어적 운율 처리에 문 제가 없다(Behrens, 1987, 1988; Ouellette \& Baum, 1994)는 주장 과 2) 우반구 손상 환자와 좌반구 손상환자 모두 언어적 운율 처 리에 문제가 있다(Balan \& Gandour, 1999)는 주장을 들 수 있으 며 그밖에 문법 정보의 유무에 따라 좌반구와 우반구에서 서로 주도적으로 처리하는 결과가 다르다는 연구 결과도 보고되었 다(Kreitewolf et al., 2014; Meyer et al., 2002).

뇌졸중(cerebrovascular accident, CVA)은 발생기전에 따라 뇌 혈관이 막히는 허혈성 뇌졸중(ischemic stroke)과 뇌혈관이 터지 는 출혈성 뇌졸중(hemorrhagic stroke)으로 분류된다(Kang et al., 2005). 출혈성 뇌졸중은 특히 중대뇌동맥(middle cerebral artery, $\mathrm{MCA}$ ) 및 기저핵(basal ganglia, $\mathrm{BG}$ ) 손상이 많은 비율을 차지하 고 있으며(Noh et al., 2016) 이로 인해 실어증과 구어운동장애를 야기시킬 수 있다. 병변 위치에 따라 피질(cortical) 뇌졸중과 피 질하(subcortical) 뇌졸중으로 구별할 수도 있는데 후자의 경우 기저핵과 시상(Thalamus)과 같은, $\mathrm{MCA}$ 로부터 분지된 작은 혈 관에 기인하는 병소와 관련되어 있다(Lin \& Marsh, 2021).

언어적 운율 처리와 관련된 대개의 연구들은 의학 영역에서 이루어졌으며 청지각적 평가와 관련하여 기능적 자기공명 영 상(functional magnetic resonance imaging, fMRI; Kreitewolf et al., 2014; Meyer et al., 2002), 양전자방출 단층 촬영술(positron emission tomography, PET), 사건 관련 뇌 전위(event-related brain potentials, ERP; Friederici \& Alter, 2004) 등과 같은 기기의 사용을 통해 자 극에 대한 뇌 활성화 반응을 보고하였다. 이들 신경 영상 연구 들은 우반구 혹은 좌반구에서의 주도적 처리는 문법정보의 유 무에 따라 다르다고 보고하였다(Kreitewolf et al., 2014; Meyer et al., 2002; Poldrack et al., 2001).

Meyer et al.(2002)은 언어적 운율 처리의 편재화(lateralization) 를 지각적(perceptual) 관점에서 살펴보기 위해 1) 자연스러운 문 장 2) 문법적으로 자연스러운 문장이지만 의미정보가 없는 문 장 3) 문법적으로 해석할 수 없는 문장으로 구성된 세 가지 발화 를 fMRI를 이용하여 살폈다. 연구결과, 문법적으로 해석할 수 없는 3) 문장의 경우 좌반구와 우반구 STR(superior temporal gyrus) 영역에서 상당히 약한 뇌 활성화 반응이 나타났지만 상 대적으로 우반구 STR 후방부 측두 평면(planum temporale)에서 더 강하게 활성화되었다. 이 결과는 측두 평면이 음도 처리에 기본적인 역할을 하기 때문일 수 있다(Perry et al., 1999). ERP를 이용한 연구결과에서도 음도 궤적(pitch contours)의 청각 처리 와 관련된 하위 상달식(bottom-up) 처리는 우반구가 주도하는 반면 어휘 성조(lexical tone)의 상부 하달식(top-down) 처리는 좌 반구에서 주도한다고 했다(Shuai \& Gong, 2014). 청지각 처리와 관련된 신경영상 연구들 중 일부는, 언어적 운율은 양쪽 반구에 서 처리되지만 좌반구와 우반구가 각각 다른 기능적 역할을 하 는데 특히 정서, 허밍(humming)과 같은 음향단서의 운율 정보 처리는 우반구에서 우세하고 통사, 의미론적 정보 처리는 좌반 구에서 우세하다는 주장을 하고 있다(Friederici \& Alter, 2004;
Kreitewolf et al., 2014; Meyer et al., 2002).

정서운율과 언어운율의 지각(perception) 관련 뇌영상 연구를 다루고 있는 메타 연구에 의하면(Belyk \& Brown, 2014) 대뇌 편 재화는 전두엽보다 측두엽의 청각처리 영역이 주도적이라는 내용을 제시한다. 그러나 더 주요한 결론은 편재화보다 반구 내 특이 영역에 주목하는 국소화(localization)라는 것이다. 연구에 의하면 대체로 우반구 측두엽에서 이 두 가지 운율 지각이 혼재 되어 처리되지만 IFG(inferior frontal gyrus, 아래이마이랑) 영역 내부에 주요한 차이점이 있는데 정서운율은 IFG 눈확 부분(pars orbitalis=브로드만 47번 영역)을 활성화시키는 것 같고, 언어운 율은 IFG 덮개 부분(pars opercularis=브로드만 44번 영역)을 활 성화시키는 것 같다고 하였다.

Gandour et al.(2003)은 문장 내 언어적 운율의 초점범위에 따 른 대뇌 반구 편재화를 연구하였다. 중국어와 영어를 대상으로 성조(tone)의 국소적(local) 영역과 억양(intonation)의 전반적 (global) 영역, 그리고 음도 윤곽(pitch contour) 처리에 초점을 두 어 대뇌반구 편재화를 살펴보았다. 그 결과, 성조 처리는 좌반 구에서 우세한 반면, 억양처리는 우반구에서 우세한 결과를 보 였다. 중국어는 성조로 낱말 뜻을 구별하므로 성조가 형태 통사 적 측면에서 주요한 기여를 한다. 그런 의미에서 좌반구 우세 처리를 지지할 수 있을 것 같다. 이 연구에서는 자극 지속시간 이 모든 과제에서 동일했기 때문에 뇌활성화 패턴에서 관찰된 차이는 초점 영역(낱말과 문장; 국소적 \& 전반적)에서의 차이 에 기인한 것으로 볼 수 있다.

발화 산출의 측면에서 $\operatorname{Behrens}(1987,1988)$ 은 단어강세와 문 장 내에서의 강세 대조 시 강도(intensity), 지속시간 및 음도 산 출에서 우반구 손상 환자가 정상화자와 다르지 않다는 결과를 냈다. 이후 1989년 연구에서, 문장수준으로 범위를 확대하여 음 향 단서의 산출능력을 정상 화자와 비교한 결과, 긴 문장에 걸 쳐 음도를 조작하는데 있어서 정상 화자에 비해 우반구 손상 환 자가 어려움을 겪는다는 결과를 내었다. 즉, 우반구 손상 환자 는 단어 수준에서는 언어적 운율을 산출하는데 있어 결함이 없 지만, 구문이나 문장수준의 운율 산출은 결함을 보일 수 있다고 제언하였다. 하지만, 연구에 좌반구 손상 환자 집단이 포함되지 않아 대뇌반구 편재화에 관해 도출할 수 있는 결론이 제한될 수 있다(Behrens, 1989).

우반구 손상 환자의 발화 산출 자료를 대상으로 한 메타연구 (Weed \& Fusaroli, 2020)에서 음도변이, 강도변이 그리고 휴지 (pause)와 리듬을 포함하는 지속시간 변이 변수를 관찰한 결과 우반구손상 환자의 음도가 상대적으로 단조롭다는 것과 문장 전체의 총 휴지 지속시간이 짧다는 특징을 보고하고 있다. 강도 와 관련해서는, 음도나 지속시간과 같은 뚜렷한 차이는 없었으 나, 적어도 표면적으로는 우반구 손상 환자가 좌반구 손상 환자 에 비해 그 변이가 적었다고 하였다. 폴란드어 자료 \{nie ma (there is no) $\}$ 를 이용한 정서(기쁨, 슬픔, 화남) 산출 연구(Guranski \& Podemski, 2015)에서는 기본주파수 변이(표준편차), 강도 평균 값, 전체발화 지속시간을 측정한 결과, 정상화자에 비해 우반구 손상 환자들의 기본주파수 변이폭이 유의하게 적었으나 음도 
궤적의 방향성은 유지하였다고 보고하였다.

Lee(2010)는 동음어가 포함된 문장 산출시 의미에 따른 장단 의 실현과 관련된 운율변화와 뇌병변을 연결하였다. 다음 두 자 료의 경우 $\{a)$ 날아다니는 벌(:)이 무섭다, b) 아버지가 내리는 벌이 무섭다 $\}$ 에서 정상화자와 우반구 손상화자는 음도 최대값 의 위치가 음절 뒤쪽에서 나타나는 경향이 유사했지만 좌반구 손상 환자는 이러한 경향이 이들 집단에 비해 낮았다. 이와 관 련지어 음도 최대값 실현 위치는 ‘장단’의 의미변화와 관련지어 ‘언어학적 운율’로 봐야 한다고 설명하였다. 이 관점을 따르면 좌반구 손상 환자의 결함과 관련이 있는 것으로 판단할 수 있다.

대뇌에서의 운율처리에 대해 편재화의 관점을 취하든 국소화 의 관점을 취하든 언급한 연구들을 참고하면 문법정보를 포함한 언어적 운율처리는 대체로 좌반구에서 처리하고, 문법정보를 포 함하지 않은 운율처리는 우반구에서 주도적 처리를 하는 것으로 판단된다. 의견 불일치를 보이는 이유는 과제의 차이, 대상자 선 정 기준 및 자료 분석 방법 차이에 기인한 것으로 생각된다.

대뇌 반구의 운율 처리과정을 이해하는 것은 인지신경과학 관점에서의 기초를 제공할 뿐 아니라 신경학적 손상 환자들의 손상 부위를 예측할 수 있고, 치료적 접근을 할 수 있는 중요한 단서가 된다. 이와 같이 대뇌반구 편재화에 관심을 두고 많은 연구가 이루어져 왔으나 운율인식과 관련하여 여러 가설들이 발표되고 있다. 국내는 아직 연구가 부족해 보인다.

이에 대뇌 편재화 관점에서 한국어의 언어적 운율처리와 관 련된 좌우 반구 각각의 상대적 우세성에 주목해 보고자 한다. 이를 위해 동일한 텍스트로 구성되었지만 문장 안에 내재된 의 문문의 조건(설명, 판별, 선택과 응답 요구)에 따라 발화 산출 시 운율에 차이를 보이는 의문사 의문문과 예-아니오 의문문, 그리고 선택의문문의 세 가지 과제를 선정하였다. 세 가지 과제를 이용하 여 좌·우반구 손상 뇌졸중 환자와 정상화자의 운율 관련 음향 변수 의 특성을 살펴보고 청지각 평가와 함께 그들 발화의 차이점을 분 석해보고자 한다. 구체적인 연구문제는 다음과 같다. 1) 의문문 유 형에 따라 운율변수들이 좌반구 손상, 우반구 손상, 정상화자 세 집단 간 차이가 있는가? 2) 의문문 유형에 따라 억양 자연성 (naturalness)에 대한 청지각 평가가 세 집단 간 차이가 있는가?

\section{2. 연구방법}

\section{1. 연구대상}

연구 대상자는 전북지역에 거주하는 남성으로 정상 화자 그 룹은 평균 연령 51.6세 $( \pm 7.2, \mathrm{~N}=9)$, 뇌졸중 환자 집단은 평균 연 령 61.4세 $( \pm 9.4, \mathrm{~N}=14)$ 이며, 총 23명이 연구에 참여하였다. 읍도 변수 분석이 가장 중요한 까닭에 피험자의 성별을 남성으로 제 한하였다. 서론에서 언급한 피질 뇌졸중과 피질하 뇌졸중군 모 두를 포괄하기 위하여 중대뇌동맥 손상군과 기저핵 손상군을 연구대상에 포함시켰다. 피험자 선별 조건은 다음과 같다. 언어적 문제가 없는 뇌졸중 환자를 피험자로 포함하기 위하여 3)과 4) 조 건이 포함되었다. 7)은 정상화자를 포괄하는 공통선별 기준이다. 연구 대상자에 대한 자세한 정보는 표 1과 표 2에 제시하였다.
1) $\mathrm{CT}$ (computed tomograpy) 또는 $\mathrm{MRI}$ (magnetic resonance imaging) 등의 영상 의학적 방법을 이용하여 신경과 혹은 신경외과 전문의로부터 뇌졸중 진단을 받은 자.

2) 좌반구 또는 우반구 중대뇌동맥 및 기저핵에서 신경학적 손상을 보이는 자.

3) K-NIHSS(Korean-National Institute of Health Stroke Scale)로 평가한 뇌졸중 척도에서 정상(K-NIHSS 0점) 경도(K-NIHSS 1점)의 손상을 보이는 자.

4) K-FAST(Korean-Frenchay Aphasia Screening Test)로 평가한 실어증 선별검사에서 실어증이 의심되지 않는 자 $(>25$ 점 [64세 미만], >20점[65세 이상]).

5) K-MMSE(Korean-Mini-Mental State Examination)로 평가한 인지평가에서 인지적 손상이 의심되지 않는 자(K-MMSE 24점 이상).

6) 주요 우울장애, 정신분열증, 양극성 장애, 치매 등의 기존 의 중대한 정신과적 질환이 동반되지 않은 자.

7) 오른손 잡이이며 읽기가 가능한 자.

표 1. 정상화자 대상자 정보

Table 1. Information of normal (control) subjects

\begin{tabular}{c|c|c}
\hline No. & 연령 & 학력 \\
\hline N1 & 57 & 대졸 \\
\hline N2 & 54 & 대학원졸 \\
\hline N3 & 63 & 무학 \\
\hline N4 & 44 & 대졸 \\
\hline N5 & 37 & 대학원졸 \\
\hline N6 & 54 & 대졸 \\
\hline N7 & 50 & 전문대졸 \\
\hline N8 & 56 & 대졸 \\
\hline N9 & 49 & 대학원졸 \\
\hline
\end{tabular}

표 2. 뇌졸중 환자 대상자 정보

Table 2. Information of stroke patients

\begin{tabular}{|c|c|c|c|c|c|c|c|c|}
\hline No. & $\begin{array}{l}\text { 연 } \\
\text { 령 }\end{array}$ & 구분 & $\begin{array}{l}\text { 병변 } \\
\text { 부위 }\end{array}$ & $\begin{array}{l}\text { 발병 } \\
\text { 기간 }\end{array}$ & 학력 & $\begin{array}{c}\text { K- } \\
\text { FAST }\end{array}$ & $\begin{array}{c}\text { K- } \\
\text { MMSE }\end{array}$ & $\begin{array}{c}\text { K- } \\
\text { NIHSS }\end{array}$ \\
\hline L1 & 55 & Infarction & $\begin{array}{c}\text { Lt.MCA } \\
\text { B.G/IC }\end{array}$ & $2 ; 10$ & 초졸 & 26 & 28 & 4 \\
\hline $\mathrm{L} 2$ & 55 & Hemorrhage & Lt.B.G & $2 ; 4$ & 고졸 & 25 & 25 & 1 \\
\hline L3 & 55 & Infarction & Lt.MCA & $2 ; 4$ & 고졸 & 27 & 30 & 2 \\
\hline L4 & 67 & Infarction & Lt.MCA & $1 ; 6$ & 중졸 & 29 & 30 & 2 \\
\hline L5 & 70 & Infarction & Lt.MCA & $0 ; 3$ & 고졸 & 25 & 26 & 1 \\
\hline L6 & 62 & Infarction & Lt.MCA & $1 ; 11$ & 고졸 & 27 & 26 & 2 \\
\hline L7 & 57 & Hemorrhage & Lt.B.G & $1 ; 3$ & 고졸 & 26 & 26 & 4 \\
\hline $\mathrm{R} 1$ & 48 & Infarction & $\begin{array}{c}\text { Rt.MCA } \\
\text { B.G/IC } \\
\end{array}$ & $2 ; 7$ & 고졸 & 29 & 30 & 4 \\
\hline R2 & 55 & Infarction & $\begin{array}{c}\text { Rt.MCA } \\
\text { B.G/IC }\end{array}$ & $1 ; 3$ & 무학 & 28 & 29 & 2 \\
\hline R3 & 54 & Infarction & $\begin{array}{c}\text { Rt.BZ } \\
\text { B.G/CR } \\
\end{array}$ & $1 ; 8$ & 대졸 & 29 & 25 & 2 \\
\hline R4 & 57 & Hemorrhage & Rt.B.G & $2 ; 9$ & 대졸 & 28 & 30 & 2 \\
\hline R5 & 69 & Infarction & $\begin{array}{c}\text { Rt.MCA } \\
\text { B.G } \\
\end{array}$ & $2 ; 1$ & 초졸 & 27 & 25 & 4 \\
\hline R6 & 87 & Infarction & Rt.MCA & $2 ; 5$ & 초졸 & 22 & 24 & 2 \\
\hline R7 & 68 & Infarction & Rt.MCA & $0 ; 1$ & 고졸 & 29 & 29 & 1 \\
\hline
\end{tabular}


2.2. 연구 절차

\subsection{1. 발화 과제}

제 2 외국어로 한국어를 배우는 사람들의 경우 그 운율 표현 에 상당한 어려움을 느낄 수 있으며 한국어 원어민이더라도 세 대에 따라 억양패턴이 달라질 수 있는 다음 세 가지 의문문을 발화과제로 선정하였다. 1) 의문사 구에 해당하는 정보를 요구 하는 의문사 의문문, 2) 문장의 진위를 묻는 예-아니오 의문문, 3) 질문의 선택 대상을 나열하고 그 선택을 응답으로 요구하는 선택의문문. 또한, 의문사 중 의문사 발달 초기인 3 세 전후 습득 된다고 보고된 ‘누가'를 의문사 구에 포함하였다(Lee \& Kwon, 2005).

의문사 의문문과 예-아니오 의문문은 서로 다른 사진을 보고 동일한 텍스트(‘누가 라면을 먹나요’)의 운율을 변별하여 산출 할 수 있는지 실험하기 위해 문장을 통일하였다. 문장을 구성하 는 음절의 수가 운율에 미치는 영향을 통제하기 위해 '8음절'로 일치시켰다. 선택의문문은 형태상 한 문장 내에서 접속사를 기 점으로 전·후 문미구 위치에 동일한 단어가 반복된다(Seo \& Seong, 2012). 반복 되는 어구의 운율 특성을 비교하기 위해 \{먹나 요\} 동사구를 문장 앞 뒤에 쌍으로 배치하였다(아래 예문 참고).

'-요'체는 의문문과 평서문에 동일한 어미로 쓰이기 때문에 문미구 운율 분석을 위해 사용하였고, 장애음의 경우 음도 분석 에 영향을 미칠 수 있기 때문에(Jung \& Seong, 2007) 문장의 첫 음절은 비음으로 시작하였다. Kim \& Seong(2014)의 선행 연구 에서 사용한 실험자료는 비음과 유음이 많이 포함되어 음도곡 선이 끊김이 없어 음향분석이 용이하다. 본 연구의 실험 조건과 가장 잘 맞는 문장이기 때문에 실험자료로 사용하였다. 사용문 장은 다음과 같다.

\section{가: 의문사 의문문: 누가 라면을 먹나요?}

나: 예-아니오 의문문: 누가 라면을 먹나요?

다: 선택의문문: 미나는 라면을 먹나요, 아니면 냉면을 먹나요?

\subsection{2. 녹음 과정}

녹음은 연구자와 대상자가 조용한 공간에서 1 대 1 조건으로 진행하였으며, 대상자에게 문장(의문사 의문문, 예-아니오 의문 문, 선택 의문문)에 적합한 3장의 상황별 사진을 보여주고, 각 문장 의미에 대해 충분히 이해시켰다. 자연스러운 발화와 동일 한 운율구 생성 패턴을 유도하기 위해 3장의 상황별 사진과 텍 스트를 함께 제시하였다. 낭독하는 것을 방지하기 위해 발화 산 출 전 대상자가 텍스트를 한번 묵독하고 대상자가 연구자에게 사진을 보여주고 질문하듯 최대한 자연스러운 산출을 하도록 했다. 자연스러운 발화산출을 위해 대상자와 연구자가 질문자응답자, 응답자-질문자의 형태로 주고받기(turn-taking)하여 각 문형에 따라 3 회 녹음하였다.

녹음은 TASCAM DR-40(TEAC, East Syracuse, NY, USA)을 이용하여 대상자의 입으로부터 $10-15 \mathrm{~cm}$ 거리를 두고 $44,100 \mathrm{~Hz}$ 표본추출률, 16 bit 양자화 조건에서 하였다. 음도 곡선이 가능
한 끈어지지 않고 연결된 가장 자연스러운 의문형 각 1 회분을 선택하여 분석에 이용하였다.

\subsection{3. 음향 분석}

음성 자료는 kPhonetica 2.08(Seong et al., 2019)을 이용, 자동 으로 분절, 레이블링 하였다. 이후 Praat(ver. 6048, Boersma \& Weenink, 2019)의 수동 보정으로 최종 레이블링(labeling)이 완 성된 데이터를 지속시간, 음도, 강도를 포함한 음향변수를 이용 해 문장, 낱말 단위에서 자동 분석하였다.

음향변수는, 선택의문문에서는 전후 2 개의 운율구 영역에서 initial_regslope(첫번째 운율구 억양 회귀 기울기: Q1)와 final_ regslope(마지막 운율구 억양 회귀 기울기: Q2)를 사용하였으며, 8 음절로 구성된 의문사 의문문과 예-아니오 의문문은 문장 전 체, 개별 낱말(처음, 중간, 마지막) 영역에서 speech rate(발화속 도), *_dev(standard deviation, 음도 및 강도 표준편차), * ${ }_{-}$range(음 도 및 강도 범위), nor_*(normalization, 음도 및 강도 정규화 변 수), reg_*(regression slope, 억양 회귀 기울기), diff_(differential slope, 억양 미분 변화량 기울기) 등의 음향변수를 사용하였다 (표 3).

발화속도는 전반적 말속도(overall speaking rate)와 조음 속도 (articulation rate)로 나누어 분석했는데 전자는 휴지(pause)를 포 함하고, 문장 음절수를 전체 문장 지속시간으로 나눈 값이며, 후자는 휴지(pause)를 제외하고, 문장 음절수를 전체 문장 지속 시간으로 나눈 값이다. 또한, 전체 문장에 대한 낱말 위치에 따 른 상대적 지속시간을 측정하였다. 어절 간 유성 펄스(voicing pulse)가 $100 \mathrm{~ms}$ 이상 끊어진 구간을 휴지구간으로 선정하여 분 절, 레이블링하였다(Miller \& Schwanenflugel, 2006). 표준편차 변수는 음도 및 강도의 표준편차로 값이 클수록 편차가 크다. 음도 및 강도 범위는 분석 구간 내 변수 최댓값과 최솟값의 차 로 구한 값이다. 정규화 변수는 문장 평균값에 대한 음도 혹은 강도 상대치로 가중치 100 을 곱한 값이다(식 1).

$$
\text { senNorpitchMax }=100 \times \frac{\text { senPitchMax }}{\text { senPitchMean }}
$$

억양 회귀 기울기는 시료 내에서 유성구간을 대상으로 프레 임 단위로 구한 주파수 값(y)의 연쇄와 각 프레임에 대응하는 시 간 값(x)를 이용하여 회귀 분석에 사용되는 최소 제곱법(least square)으로 구한 값이다(식 2). 식 (2)에서 $\bar{x}$ 는 측정구간 시간 포인트 평균값이고 $\bar{y}$ 는 주파수 평균값이다. 측정 구간 중간에 분포되어 있는 다양한 음도 변이값들을 포관하고 시간변화량 이 커질수록 기울기가 왜곡될 수 있는 점을 보완해준다. 최소 제곱법을 이용하여 구하면 실제 분포된 변수들의 값들로부터 가장 오차가 적은 직선을 찾아낼 수 있는 장점이 있다.

$$
\text { Reg slope }=\frac{\sum(x-\bar{x})(y-\bar{y})}{\sum(x-\bar{x})^{2}}
$$


미분 변화량 기울기(differential slope)는 선택 영역의 마지막 시간 부분에서 시작 부분 음도를 뺀 값(f2-f1)을 선택 구간 시간 양 $(\triangle$ duration)으로 나눈 전통적 개념의 미분 기울기 값이다.

표 3. 분석에 이용된 음향변수

Table 3. Acoustic variables used in analysis

\begin{tabular}{|c|c|c|}
\hline & 특성 & 음향 변수 \\
\hline \multirow{4}{*}{ Tempo } & \multirow{2}{*}{ Speech rate } & overall speaking rate \\
\hline & & articulation rate \\
\hline & \multirow{2}{*}{ Relative duration } & initial_word_relDur \\
\hline & & final_word_relDur \\
\hline \multirow{11}{*}{ Pitch } & Standard deviation & senPitchDev \\
\hline & \multirow{3}{*}{ Pitch range } & senPitchRange \\
\hline & & initial word PitchRange \\
\hline & & final_word_PitchRange \\
\hline & \multirow{7}{*}{$\begin{array}{c}\text { Normalized } \\
\text { variables }\end{array}$} & senNorPitchMax \\
\hline & & initial word NorPitchMax \\
\hline & & initial_word_NorPitchMedian \\
\hline & & initial_word_NorPitchMean \\
\hline & & final word NorPitchMax \\
\hline & & final_word_NorPitchMedian \\
\hline & & final_word_NorPitchMean \\
\hline \multirow{9}{*}{ Intensity } & Standard deviation & senIntDev \\
\hline & Intensity range & senIntRange \\
\hline & \multirow{7}{*}{$\begin{array}{l}\text { Normalized } \\
\text { variables }\end{array}$} & senNorIntMax \\
\hline & & initial_word_NorIntMax \\
\hline & & initial_word_NorIntMedian \\
\hline & & initial word NorIntMean \\
\hline & & final_word_NorIntMax \\
\hline & & final_word_NorIntMedian \\
\hline & & final_word_NorIntMean \\
\hline \multirow{5}{*}{$\begin{array}{l}\text { Intonation } \\
\text { slope }\end{array}$} & \multirow{3}{*}{ Regression slope } & initial_word_regSlope \\
\hline & & Q1(2)_regSlope \\
\hline & & final_word_regSlope \\
\hline & \multirow{2}{*}{ Differential slope } & initial_word_diffSlope \\
\hline & & final_word_diffSlope \\
\hline
\end{tabular}

2.3. 청지각 평가 및 신뢰도

대상자들이 세 가지 유형 의문문에 내포된 운율 특성을 자연 스럽게 산출했는지 살펴보기 위해 청지각 평가를 하였다. 의문 사 문형별 억양 특성에 대한 이해도가 높은 5명의 언어재활사 가 참가하였다. 2 년 이상의 임상경력과 2 급 이상의 언어 재활사 자격증을 소지한 자들이다. 본 평가에 앞서 Praat의 experimentMFC 실험 플랫폼과 자극 제시 방식에 익숙해질 수 있도록 예행 연습 세션을 가진 뒤, 본 평가에 들어갔다.

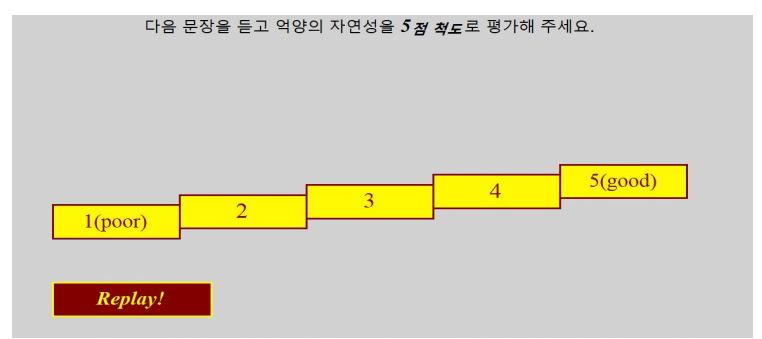

그림 1. 청지각 평가용 Praat experimentMFC 화면

Figure 1. Praat's experimentMFC screen copy for auditory perceptual test
실험 과제는 평가자내 일치도를 평가하기 위한 dummy 자극 6 개를 포함하여 문형 당 27 개의 음성 자극으로 구성되었고, 2 회 반복하여 시행했기 때문에 총 자극 문장은 54문장이다. 평가자 에게 음성자료를 듣고 억양의 자연성(naturalness)을 5점 척도로 평가하도록 하였다. 자연성의 정도는 ‘매우 부자연스러움' 1점, ‘부자연스러움’ 2점, ‘보통' 3점, ‘자연스러움’ 4점, ‘매우 자연스 러움' 5점이다(그림 1).

평가자내 신뢰도의 경우, Spearman's 순위 상관 분석 결과, 의문 사 의문문( $r=810)$, 예-아니오 의문문( $r=.870)$, 선택 의문문( $r=.835)$ 모두 높은 상관관계를 보이며 유의하였고 $(p<.01)$, 감마 계수 역 시 의문사 의문문 .841 , 예-아니오 의문문 .902, 선택의문문 .885 의 일치도를 보이며 모두 유의하였다 $(p<.001)$. 평가자간 신뢰도 의 경우 ICC(intraclass correlation coefficient) 평균측도(AMI)와 단일측도(SMI)가 의문사 의문문(AMI $=.719, \mathrm{SMI}=.339, p<.001)$, 예-아니오 의문문(MI=.833, SMI=.499, $p<.001)$, 선택 의문문 $(\mathrm{AMI}=.845, \mathrm{SMI}=.522, p<.001)$ 으로 나왔다. 일반적으로 단일측 도가 0.3 이상으로 나오면 평가자간 신뢰도가 있는 것으로 판단 할 수 있다(Lee et al., 2010).

\section{4. 통계}

SPSS version 24.0(IBM, Armonk, NY, USA)을 사용하여 통계 분석 하였다. 표본수가 적어 정규분포를 이루지 않으므로 크루 스칼 왈리스(Kruskal Wallis) 검정으로 집단 간 평균 순위차를 검 정한 뒤 유의한 차이가 관찰되는 변수에 대해 다시 원 자료의 양적변수를 순위변수로 전환하고 일원배치 분산분석으로 사후 검정을 하였다. 사후검정으로 등분산이 가정된 표본의 경우는 Tukey HSD를 사용하고 등분산이 가정되지 않은 표본은 GamesHowell을 사용하였다. 청지각 분석은 평가자 내 일치도 검정을 위해 Spearman's 순위 상관 분석 및 교차 분석의 감마 값을 이용 하였으며, 평가자 간 신뢰도는 ICC를 이용하였다. 억양 자연성 에 대한 청지각 평가 결과를 해석하기 위해서 카이제곱 검정을 실시하였고 각 의문문 유형별로 세 집단(좌반구손상, 정상, 우 반구손상)간 평가점수의 차이점을 살펴보기 위하여 일원분산 분석과 Bonferroni 사후검정을 실시하였다.

\section{3. 연구 결과}

3.1. 의문사 의문문과 예-아니오 의문문 운율분석

\subsection{1. 의문사 의문문과 예-아니오 의문문의 발화속도와 지속시간분석}

의문사 의문문과 예-아니오 의문문의 지속시간 분석 결과, 총 4 개 중 2개의 음향변수에서 유의한 차이를 보였다. Overall speaking $\operatorname{rate}(p<.01)$ 와 articulation $\operatorname{rate}(p<.05)$ 는 두 개 의문문 유형 모두에 서 집단간 유의한 차이를 보였다(표 4). 유의한 차이를 보인 음 향 번수에 대한 사후검정 결과 두 음향 변수 모두 좌반구 손상 환자가 정상 화자에 비해 발화속도가 느렸다 $(p<.05$, 그림 2$)$. 
표 4. 의문사 의문문과 예-아니오 의문문의 발화속도 및 문두 및 문미 낱말의 상대적 지속시간 비율 크루스칼 왈리스 검정

Table 4. Kruscal-Wallis test of speeech rate, sentence initial \& final word relative duration ratio regarding Wh-question and Yes-No question

\begin{tabular}{c|c|c|c|c|c}
\hline 음향변수 & \multicolumn{2}{|c|}{} & $\chi^{2}$ & $d f$ & $p$-value \\
\hline \multirow{2}{*}{ Overall speaking rate } & \multirow{2}{*}{ 집단 } & 의문사 & 9.409 & 2 & $.009^{* *}$ \\
\cline { 3 - 6 } & & 예-아니오 & 8.082 & 2 & $.018^{*}$ \\
\hline \multirow{2}{*}{ Articulation rate } & \multirow{2}{*}{ 집단 } & 의문사 & 9.409 & 2 & $.009^{* *}$ \\
\cline { 3 - 6 } & & 예-아니오 & 8.082 & 2 & $.018^{*}$ \\
\hline \multirow{2}{*}{ Initial_word_relDur } & \multirow{2}{*}{ 집단 } & 의문사 & 1.759 & 2 & .415 \\
\cline { 3 - 6 } & & 예-아니오 & 0.364 & 2 & .834 \\
\hline \multirow{2}{*}{ Final_word_relDur } & \multirow{2}{*}{ 집단 } & 의문사 & 4.297 & 2 & .117 \\
\cline { 3 - 6 } & & 예-아니오 & 3.948 & 2 & .139 \\
\hline
\end{tabular}
${ }^{*} p<.05,{ }^{* *} p<.01$.

\section{whQ speakingRate(a)}
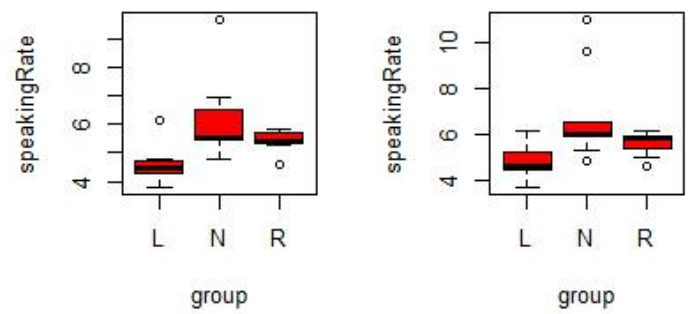

whQ articulationRate(c)

ynQ articulationRate(d)
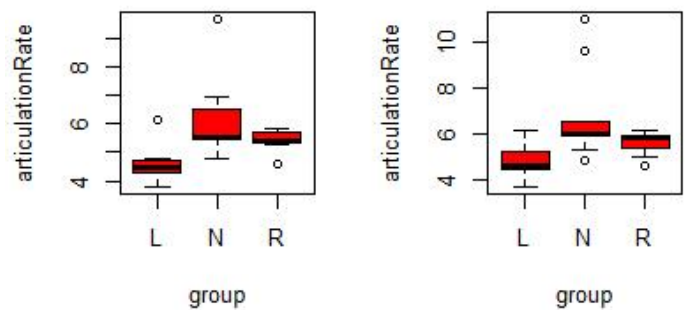

그림 2. 의문사 의문문과 예-아니오 의문문의 발화 속도 상자 그림(중앙값과 4분위수, 최대, 최소, $\mathrm{L}=\mathrm{left}$ hemisphere damaged patients, $\mathrm{N}=$ normal, $\mathrm{R}=$ right hemisphere damaged patients, the same hereafter) (a) 의문사 의문문의 말속도, (b) 예-아니오 의문문의 말속도,

((c) 의문사 의문문의 조음 속도, (d) 예-아니오의문문의 조음 속도

Figure 2. Box plot of speech tempo regarding Wh-question and Yes-No question (median, quatrile, maximum, \& minimum; L=left hemisphere damaged patients, $\mathrm{N}=$ normal, $\mathrm{R}=$ right hemisphere damaged patients, the same hereafter) (a) speaking rate of Wh-question, (b) speaking rate of yes-no question, (c) articulation rate of Wh-question, (d) articulation rate of Yes-No question

3.1.2. 의문사 의문문과 예-아니오 의문문의 음도와 억양 기울기 분석

의문사 의문문과 예-아니오 의문문의 음도와 억양 기울기 분 석 결과, 총 21 개 변수 중 2개 음향변수에서 유의한 차이를 보였 다( $p<.05)$. final_word pitchRange는 두 개 의문문 유형 모두에서 차이가 났고, initial_word_diffSlope는 의문사 의문문에서 유의 한 차이를 보였다(표 5). 유의한 차이를 보인 음향변수에 대한 사후검정 결과 2 개 음향변수 모두 좌반구 손상환자와 정상 화 자 사이에서 유의한 차이를 보였다 $(p<.05$, 그림 3$)$.
표 5. 의문사 의문문과 예-아니오 의문문의 음도 변수 크루스칼 왈리스 검정

Table 5. Kruscal-Wallis test of pitch relevant variables regarding Wh-question and Yes-No question

\begin{tabular}{l|c|c|c|c|c}
\hline \multicolumn{2}{|c|}{ 음향변수 } & \multicolumn{2}{|c|}{$\chi^{2}$} & $d f$ & $p$-value \\
\hline \multirow{2}{*}{ Final_word_PitchRange } & \multirow{2}{*}{ 집단 } & 의문사 & 6.685 & 2 & $.035^{*}$ \\
\cline { 3 - 6 } & & 예-아니오 & 6.112 & 2 & $.047^{*}$ \\
\hline \multirow{2}{*}{ Initial_word_diffSlope } & \multirow{2}{*}{ 집단 } & 의문사 & 6.565 & 2 & $.038^{*}$ \\
\cline { 3 - 6 } & & 예-아니오 & 3.786 & 2 & .151 \\
\hline${ }^{*} p<.05$.
\end{tabular}

whQ f_pitchRange(a)

ynQf_pitchRange(b)
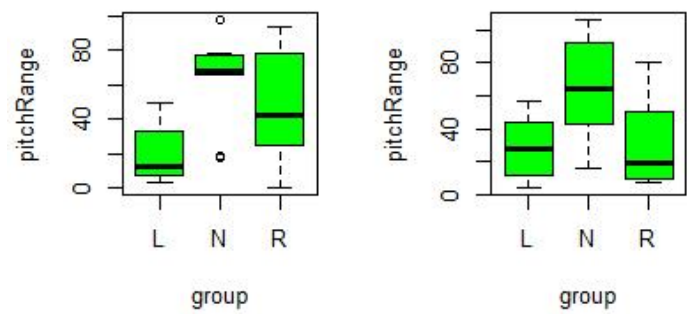

whQ diff_i_slope(c)

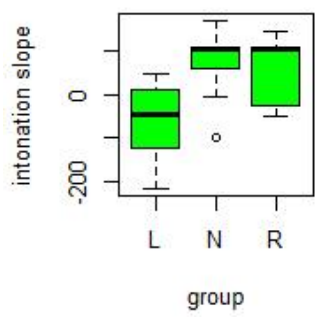

그림 3. 의문사 의문문과 예-아니오 의문문의 음도 변수 상자 그림(중앙값과 4 분위수, 최대, 최소) (a) 의문사 의문문의 마지막 낱말 음도 범위, (b) 예-아니오 의문문의 마지막 낱말 음도 범위, (c) 의문사 의문문의 첫 낱말 변화량 기울기

Figure 3. Box plot of pitch variables of Wh-question and Yes-No question

(a) final word pitch range of Wh-question, (b) final word pitch range of Yes-No question, (c) differential slope of initial word of Yes-No question

\subsection{3. 의문사 의문문과 예-아니오 의문문의 강도분석}

의문사 의문문과 예-아니오 의문문의 강도 분석 결과, 2 개 음 향변수에서 유의한 차이를 보였다( $p<.05)$. SenIntDev는 예-아니 오 의문문에서, initial_word_NorIntMax는 의문사 의문문에서 유 의한 차이를 보였다(표 6). 유의한 차이를 보인 음향변수에 대한 사후검정 결과 senIntDev는 우반구 손상환자와 정상 화자 사이 에, initial_word_NorIntMax는 정상화자와 좌반구, 정상화자와 우 반구 손상환자 사이에 유의미한 차이를 보였다 $(p<.05$, 그림 4$)$. 
표 6. 의문사 의문문과 예-아니오 의문문의 강도변수 크루스칼 왈리스 검정

Table 6. Kruscal-Wallis test of intensity relevant variables regarding Wh-question and Yes-No question

\begin{tabular}{|c|c|c|c|c|c|}
\hline 음향변수 & & & $x^{2}$ & $d f$ & $p$-value \\
\hline \multirow{2}{*}{ senIntMedian } & \multirow{2}{*}{ 집단 } & 의문사 & 0.353 & 2 & .838 \\
\hline & & 예-아니오 & 1.642 & 2 & .44 \\
\hline \multirow{2}{*}{ senIntDev } & \multirow{2}{*}{ 집단 } & 의문사 & 5.59 & 2 & .061 \\
\hline & & 예-아니오 & 6.565 & 2 & $.038^{*}$ \\
\hline \multirow{2}{*}{ senIntRange } & \multirow{2}{*}{ 집단 } & 의문사 & 5.504 & 2 & .064 \\
\hline & & 예-아니오 & 3.528 & 2 & .171 \\
\hline \multirow{2}{*}{ senNorIntMax } & \multirow{2}{*}{ 집단 } & 의문사 & 5.736 & 2 & .057 \\
\hline & & 예-아니오 & 5.724 & 2 & .057 \\
\hline \multirow{2}{*}{ initial_word_NorIntMax } & \multirow{2}{*}{ 집단 } & 의문사 & 6.464 & 2 & $.039^{*}$ \\
\hline & & 예-아니오 & 3.391 & 2 & .183 \\
\hline \multirow{2}{*}{ initial_word_NorIntMedian } & \multirow{2}{*}{ 집단 } & 의문사 & 1.21 & 2 & .546 \\
\hline & & 예-아니오 & 0.364 & 2 & .834 \\
\hline \multirow{2}{*}{ initial_word_NorIntMean } & \multirow{2}{*}{ 집단 } & 의문사 & 4.148 & 2 & .126 \\
\hline & & 예-아니오 & 3.495 & 2 & .174 \\
\hline \multirow{2}{*}{ final_word_NorIntMax } & \multirow{2}{*}{ 집단 } & 의문사 & 2.456 & 2 & .293 \\
\hline & & 예-아니오 & 0.386 & 2 & .825 \\
\hline \multirow{2}{*}{ final_word_NorIntMedian } & \multirow{2}{*}{ 집단 } & 의문사 & 0.067 & 2 & .967 \\
\hline & & 예-아니오 & 0.089 & 2 & .956 \\
\hline \multirow{2}{*}{ final_word_NorIntMean } & \multirow{2}{*}{ 집 단 } & 의문사 & 0.386 & 2 & .825 \\
\hline & & 예-아니오 & 0.002 & 2 & .999 \\
\hline \multirow{2}{*}{ Int_ratio } & \multirow{2}{*}{ 집단 } & 의문사 & 1.103 & 2 & .576 \\
\hline & & 예-아니오 & 4.557 & 2 & .102 \\
\hline \multirow{2}{*}{ senInt_90 } & \multirow{2}{*}{ 집단 } & 의문사 & 1.032 & 2 & .597 \\
\hline & & 예-아니오 & 4.549 & 2 & .103 \\
\hline
\end{tabular}

ynQ sen_int_dev(a)

WhQ iniWord_norlntMax(b)
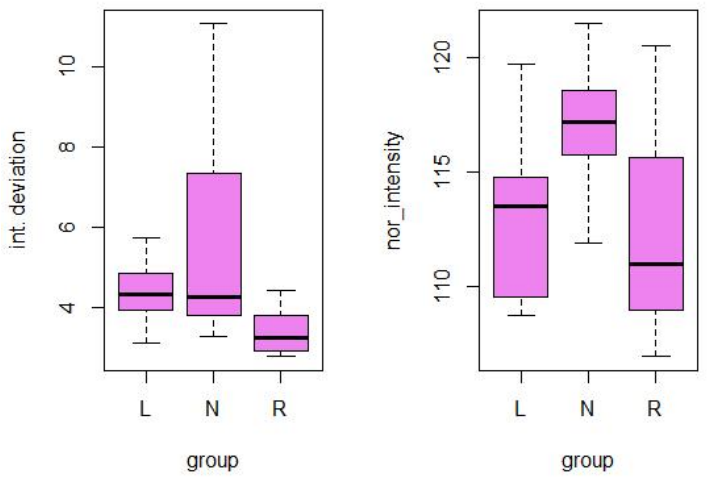

그림 4. 예-아니오 의문문의 문장강도편차와 의문사 의문문의 문두낱말 정규화 강도 최대값의 상자그림(중앙값과 4분위수, 최대,

최소). (a) 예-아니오 의문문의 문장 강도 표준편차 (b) 의문사 의문문의 문두 낱말 정규화 강도 최대값

Figure 4. Box plot of sentence intensity deviation of Yes-No question and sentence-initial word normalized maximum intensity of Wh-question. (a) sentence intensity deviation of Yes-No question, (b) sentence-initial word normalized maximum intensity

3.2. 선택의문문의 2 개 운율구 $\{$ 먹나요 $\}$ 의 억양 기울기 분석

선택의문문 문장 중간에 출현한 \{먹나요: Q1\}와 문미 \{먹나 요: Q2\}의 억양 기울기 분석 결과 initial_regslope(Q1 slope)와
final_regslope(Q2 slope) 음향변수 모두 선택 의문문에서 집단간 유의한 차이를 보이지 않았다(표 7).

\section{표 7. 선택의문문 운율구 $\mathrm{Q} 1$ (문중 \{먹나요\})과 $\mathrm{Q} 2$ (문미 \{먹나요\})의 회귀 기울기 분석 결과}

Table 7. Kruscal-Wallis test of intonation slope of Q1 prosodic phrase (sentence medial [mıynajo]) and Q2 prosodic phrase (sentence final [mınnajo]) regarding alternative question

\begin{tabular}{c|c|c|c|c}
\hline 음향변수 & & $\chi^{2}$ & $d f$ & $p$-value \\
\cline { 1 - 2 } Q1_regslope & \multirow{2}{*}{ 집 단 } & 4.834 & 2 & .089 \\
\cline { 1 - 3 } & & 2.486 & 2 & .289 \\
\hline Q2_regslope & &
\end{tabular}

\section{3. 청지각 평가}

의문사 의문문 발화 자극의 억양 자연성을 평가자들이 5 점 척도로 청지각 평가한 결과에 대한 카이제곱 검정은 통계적으 로 유의하였다 $\left(X^{2}=34.806, p<.05\right)$. Dummy 자극 6 개를 제외하고 남은 21 개 자극을 2회 반복하는 청지각 평가 실험이었으므로 투입된 본 자극은 42 개가 된다. 5 명의 평가자가 참여했으므로 전체 평가수는 210 개 $(42 \times 5=210)$ 가 되며 세 가지 의문문 문형을 대상으로 했으므로 각 문형당 70 개 자극이 배당된다. 70 개 자극 에 대한 평가 점수를 종속변수로, 세 집단(우반구 손상, 좌반구 손상, 정상 집단)을 독립변수로 하여 일원분산분석 검정한 결과 세 집단 간 통계적으로 유의한 차이가 있음이 관찰되었다 $\left[F_{(2,}\right.$ $\left.{ }_{207)}=18.266, p<.001\right]$. 본페로니 사후검정 결과 비교 집단 모든 수 준에서 유의한 차이가 있음이 밝혀졌다(표 8).

표 8. 의문사 의문문 억양 자연성에 대한 청지각 평가 사후검정 Table 8. Bonferroni post hoc test on the perceptual evaluation regarding the intonation naturalness of Wh-question

\begin{tabular}{c|c|c}
\hline Group(i)-group(j) & Mean difference $(\mathrm{i}-\mathrm{j})$ & $p$-value \\
\hline $\mathrm{L} \mathrm{N}$ & -1.27 & $.000^{* * *}$ \\
\hline $\mathrm{L} \mathrm{R}$ & -.57 & $.022^{*}$ \\
\hline $\mathrm{R} \mathrm{N}$ & -.7 & $.003^{* *}$ \\
${ }^{*} p<.05,{ }^{* *} p<.01,{ }^{* * *} p<.001$.
\end{tabular}

청지각 평가 점수 평균값은 정상화자 3.74( $( \pm 1.25)$ 점, 우반구 손상 화자 3.04( \pm 1.29$)$ 점, 좌반구 손상 화자 $2.47( \pm 1.20)$ 점으로 나 타났다. 특히 좌반구 화자가 두드러지게 낮았다. 평가 점수에 대 한 평가자들 점수 분포는 표 9의 교차분석 내용을 참고하라. 좌 반구 손상 화자에서 41 개(58.6\%)가 부자연스러움(response<3), 우반구 손상화자에서 30 개( $42.9 \%$ )가 부자연스러움으로 평가 되었다. 상대적으로 좌반구 손상화자에 대한 부자연스러움 평 가 비율이 높았음을 알 수 있다. 
표 9. 의문사 의문문 억양 자연성에 대한 청지각 평가 교차분석표(response $1=$-poor, $5=\mathrm{good}, \mathrm{L}=\mathrm{left}$ hemisphere disorder, $\mathrm{N}=$ normal, $\mathrm{R}=$ right hemisphere disorder)

Table 9. Cross table of the perceptual evaluation regarding the intonation naturalness of Wh-question (response $1=$ poor, $5=$ good, $\mathrm{L}=\mathrm{left}$ hemisphere disorder, $\mathrm{N}=$ normal, $\mathrm{R}=$ right hemisphere disorder)

\begin{tabular}{c|c|c|c|c|c|c|c}
\hline \multicolumn{2}{c|}{} & \multicolumn{7}{c|}{ Response } & \multirow{2}{*}{ Total } \\
\cline { 3 - 8 } \multicolumn{2}{c|}{} & 1 & 2 & 3 & 4 & 5 & \\
\hline \multirow{3}{*}{ Group } & L & 16 & 25 & 14 & 10 & 5 & 70 \\
\cline { 2 - 8 } & $\mathrm{N}$ & 2 & 14 & 11 & 16 & 27 & 70 \\
\cline { 2 - 8 } & $\mathrm{R}$ & 6 & 24 & 15 & 11 & 14 & 70 \\
\hline \multicolumn{2}{c|}{ Total } & 24 & 63 & 40 & 37 & 46 & 210 \\
\hline
\end{tabular}

예-아니오 의문문 발화 자극(stimuli)의 억양 자연성을 5점 척 도로 청지각 평가한 결과에 대한 카이제곱 검정은 통계적으로 유의하였다 $\left(\chi^{2}=44.507, p<.05\right)$. 평가에 사용된 70 개 자극에 대한 평가 점수를 종속변수로, 세 집단을 독립변수로 하여 일원분산 분석 검정한 결과 세 집단간 통계적으로 유의한 차이가 있음이 관찰되었다 $\left[F_{(2,207)}=17.735, p<.001\right]$. 본페로니 사후검정 결과 좌 반구 손상 집단과 정상 집단 그리고 우반구 손상 집단과 정상 집단 사이에 유의한 차이가 있음이 관찰되었다(표 10).

표 10. 예-아니오 의문문 억양 자연성에 대한 청지각 평가 사후검정 Table 10. Bonferroni post hoc test on the perceptual evaluation regarding the intonation naturalness of Yes-No question

\begin{tabular}{|c|c|c|}
\hline Group(i)-group(j) & Mean difference $(\mathrm{i}-\mathrm{j})$ & $p$-value \\
\hline L N & -1.286 & $.000^{* * *}$ \\
\hline L $\quad \mathrm{R}$ & -.271 & .703 \\
\hline $\mathrm{R} \quad \mathrm{N}$ & -1.014 & $.000^{* * *}$ \\
\hline
\end{tabular}

청지각 평가 평균값은 정상 화자 $3.8( \pm 1.24)$ 점, 우반구 손상 화자 2.8( \pm 1.39$)$ 점, 좌반구 손상 화자 2.5( \pm 1.4$)$ 점으로 나타났다. 평가 점수에 대한 평가자들 점수 분포는 표 11을 참고하라. 예-아 니오 의문문의 억양 자연성은 좌반구 손상 화자에서 44 개(62.9\%) 가 부자연스러움으로, 우반구 손상 화자에서 37 개(52.9\%) 자극이 부자연스러움으로 평가되었다. 대조군인 정상화자는 11 개(15.7\%) 자극이 부자연스러움으로 평가되었다.

표 11. 예-아니오 의문문 억양 자연성에 대한 청지각 평가 교차분석표

Table 11. Cross table of the perceptual evaluation regarding the intonation naturalness of Yes-No question

\begin{tabular}{c|c|r|r|r|r|r|c}
\hline \multicolumn{2}{c|}{} & \multicolumn{7}{|c|}{ Response } & \multirow{2}{*}{ Total } \\
\cline { 3 - 9 } \multicolumn{2}{c|}{} & 1 & 2 & 3 & 4 & 5 & \\
\hline \multirow{3}{*}{ Group } & L & 17 & 27 & 12 & 0 & 14 & 70 \\
\cline { 2 - 8 } & $\mathrm{N}$ & 4 & 7 & 16 & 14 & 29 & 70 \\
\cline { 2 - 8 } & $\mathrm{R}$ & 13 & 24 & 9 & 12 & 12 & 70 \\
\hline \multicolumn{2}{c|}{ Total } & 34 & 58 & 37 & 26 & 55 & 210 \\
\hline
\end{tabular}

선택 의문문 발화 자극(stimuli)의 억양 자연성을 평가자들이 5 점 척도로 청지각 평가한 결과에 대한 카이제곱 검정은 통계 적으로 유의하였다 $\left(\chi^{2}=52.800, p<.05\right)$. 평가 점수를 종속변수로
하고, 세 집단을 독립변수로 하여 일원분산분석 검정한 결과 세 집단간 통계적으로 유의한 차이가 있음이 관찰되었다 $[F(2,207)=$ $27.959, p<.001]$. 본페로니 사후검정 결과 좌반구 손상 집단과 정 상 집단 그리고 우반구 손상 집단과 정상 집단 사이에 유의한 차이가 있음이 관찰되었다(표 12).

표 12. 선택 의문문 억양 자연성에 대한 청지각 평가 사후검정 Table 12. Bonferroni post hoc test on the perceptual evaluation regarding the intonation naturalness of choice question

\begin{tabular}{|c|c|c|}
\hline Group(i)-group(j) & Mean difference $(\mathrm{i}-\mathrm{j})$ & $p$-value \\
\hline L N & -1.429 & $.000^{* * *}$ \\
\hline L $\quad \mathrm{R}$ & -.243 & .709 \\
\hline $\mathrm{R} \quad \mathrm{N}$ & -1.186 & $.000^{* * *}$ \\
\hline
\end{tabular}

70개 자극을 분석한 평균값은 정상 화자 $3.9( \pm 1.15)$ 점, 우반구 손상 화자 2.7 $( \pm 1.22)$ 점, 좌반구 손상 화자 2.5( \pm 1.26$)$ 점으로 나타 났다. 특히 좌반구 화자가 두드러지게 낮았다. 선택 의문문의 억양 자연성은 좌반구 손상 화자에서 42개(59.1\%)가 부자연스 러움으로 평가되었고, 우반구 손상 화자에서 32개(45.7\%) 자극 이 부자연스러움으로 평가되었다. 대조군인 정상화자는 8 개 (11.4\%) 자극이 부자연스러움으로 평가되었다(표 13).

표 13. 선택 의문문 억양 자연성에 대한 청지각 평가 교차분석표

Table 13. Cross table of the perceptual evaluation regarding the intonation naturalness of choice question

\begin{tabular}{c|c|c|c|c|c|c|c}
\hline \multicolumn{2}{c|}{} & \multicolumn{7}{c|}{ Response } & \multirow{2}{*}{ Total } \\
\cline { 3 - 8 } \multicolumn{2}{c|}{} & 1 & 2 & 3 & 4 & 5 & \\
\hline \multirow{3}{*}{ Group } & $\mathrm{L}$ & 16 & 26 & 14 & 6 & 8 & 70 \\
\cline { 2 - 8 } & $\mathrm{N}$ & 4 & 4 & 13 & 22 & 27 & 70 \\
\cline { 2 - 8 } & $\mathrm{R}$ & 12 & 20 & 20 & 11 & 7 & 70 \\
\hline \multicolumn{2}{c|}{ Total } & 32 & 50 & 47 & 39 & 42 & 210 \\
\hline
\end{tabular}

각 의문문의 억양 자연성에 대한 청지각 평가 결과는 그림 5 에 제시하였다. 
choiceQ naturalness(a)
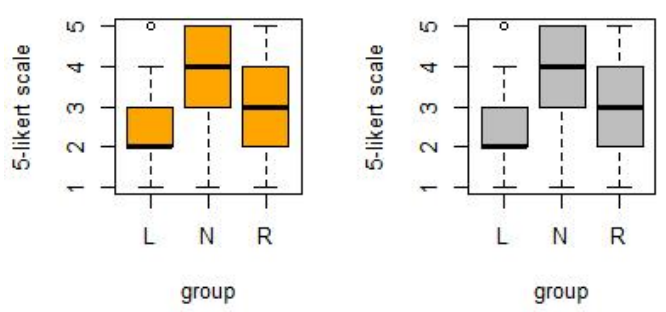

ynoQ naturalness(b)

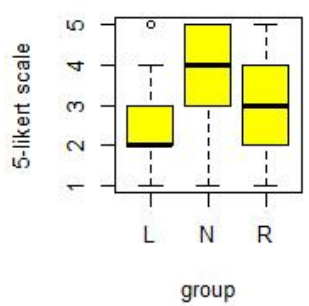

그림 5. 억양 자연성에 대한 청지각 평가(중앙값과 4분위수, 최대, 최소) (a) 의문사 의문문의 억양 자연성, (b) 예-아니오 의문문의 억양 자연성, (c) 선택의문문의 억양자연성

Figure 5. Auditory perceptual evaluation on the naturalness of intonation (a) intonation naturalness of Wh-question, (b) intonation naturalness of Yes-No question, (c) intonation naturalness of choice question

\section{4. 결론 및 논의}

좌반구와 우반구 중 어느 쪽에서 언어적 운율이 처리되는지 대뇌 편재화의 관점에서 세 집단(좌반구 손상 뇌졸중 화자, 우 반구 손상 뇌졸중 화자, 정상 화자)을 대상으로 세 가지 형태 의 문문(의문사 의문문, 예-아니오 의문문, 선택 의문문)에서의 발 화속도, 지속시간, 음도, 그리고 강도와 관련된 운율 특징을 청 지각 평가와 함께 살펴보았다.

발화속도 관련 음향변수는 의문사 의문문과 예-아니오 의문 문에서 좌반구 손상 화자가 다른 집단에 비해 유의하게 느린 말 속도로 조음하였다. 복잡한 통사의미적 내용을 대뇌에서 처리 하는데 시간이 더 걸렸음을 의미한다. 이 결과는 단어 및 문장 강세 대조에서 우반구 손상 환자가 정상화자와 지속시간에서 다르지 않다는 보고를 한 Behrens(1987, 1988)의 결과에서 지지 받을 수 있다. Weed \& Fusaroli(2020)는 우반구손상 환자가 좌반 구손상 환자 혹은 정상화자에 비해 문장전체 총 휴지 시간 (pause duration)이 짧다는 특징을 보고하였는데 휴지 시간이 짧 아지면 계산에 휴지기를 포함하지 않는 조음속도의 경우 그 값 이 커질 수 있으므로 우반구손상 환자가 비교집단에 비해 오히 려 조음속도가 빨라진다는 이상한 결과라 할 수 있다. 본 연구 에서 좌반구 손상 환자와 우반구 손상 환자 사이의 차이는 없었 으며 우반구 손상환자와 정상집단 사이의 차이도 없었다. 우반 구손상 환자와 정상화자 집단만 사용한 Guranski \& Podemski (2015)에서는 중립문장에서 우반구손상 환자가 정상화자보다 길게 발화하였다. 발화속도의 관점에서 느리게 발화한 것이다. 그러나 이 연구는 좌반구손상 환자와의 비교가 없어서 아쉽다.
2 개 어절, 2 개 음절(혹은 3 음절)로 이루어진 짧은 자료 $\{$ nie ma\} 를 읽은 것이라서 본 논문에서 다루고 있는 문법적 복잡성이 가 미되고 꽤 긴 문장에서 나온 결과와는 직접 비교가 힘들다. 좌 반구 처리가 개입할 시간 분량이 절대적으로 작은 자료라는 것 이 직접 비교를 힘들게 한다.

음도 음향변수에서 통계적으로 유의하게 작용한 변수는 문 장의 일부에서 작용하는 마지막 낱말 음도범위와 첫 낱말 변화 량 기울기였다. 문형별 음향변수의 세부적 특징을 살펴보면 의 문사 의문문의 경우 마지막 낱말 음도 범위가 좌반구 손상 화자 에서 더 좁게 나타났다. 첫 낱말의 변화량 기울기는 정상 화자 에 비해 좌반구 손상화자에서 낮게 나타났는데 이는 복잡한 문 장을 처리하는 인지 기능이 상실되면서 의문사구가 포함된 첫 낱말에 운율 정보를 싣는 능력의 결함으로 판단된다. 유의확률 90\% 유사 유의도 수준을 적용할 때, 문두 낱말 회귀 기울기는 의문사 의문문에서 좌반구 손상화자의 변화 정도가 적었으며, 문미 낱말 회귀 기울기도 상대적으로 좌반구 손상화자에서 완 만하게 나타났다. 이러한 결과 역시 위 관찰과 같은 맥락에서 해석할 수 있다.

예-아니오 의문문에서는 마지막 낱말 음도 범위 변수에서만 통계적으로 유의한 차이가 나타났다. 이 문형 또한 좌반구 손상 화자에서 음도 범위가 더 좁게 나타났다. 선택 의문문(미나는 라면을 $\{\mathrm{Q} 1$ : 먹나요\} 아니면 냉면을 $\{\mathrm{Q} 2$ : 먹나요?\})의 2개 운율 구 억양 기울기에서 첫 번째 운율구(Q1) 억양 기울기와 마지막 운율구 $(\mathrm{Q} 2)$ 억양 기울기는 집단 간 유의한 차이를 보이지 않았 지만, alpha $90 \%$ 수준 유사 유의도에서는 첫 번째 운율구(Q1) 음 도 회귀 기울기에서 좌반구 손상 화자의 상승 기울기가 다른 두 집단에 비해 매우 완만하게 나타났다고 볼 수 있다. 보통의 한 국어 화자들이 산출하는 Q1 상승 기울기 비율을 보여주지 못한 것이다.

언급한 음도와 억양 기울기 변수들은 문장의 앞부분이나 뒷 부분의 특징만을 보여주는 지역적 변수(local variables)다. 문장 전체의 특징을 보여주는 전역변수(global variables)에 해당하는 음도편차(senPitchDev)나 음도폭(senPitchRange), 정규화 변수 (senNorPitchMax)는 집단 간 차이를 보여주는 유의한 변수로 판 명되지 않았다. 그간의 연구들을 살펴보면 문장 전체를 관장하 는 전역변수는 우반구에서 처리된다는 것이 통설이다. Shuai \& Gong(2014)은 뇌신경영상 연구와 관련하여 음도의 대략적 윤곽 은 우반구가 주도한다고 했고 Gandour et al.(2004)은 문장 전반 을 관통하는 억양 생성, 산출에 우반구가 관여한다는 의견을 내 놓았다. Behrens(1989)의 경우 문장 억양을 산출하는 데 있어 우 반구손상 환자가 어려움을 겪는다고 하였고 Weed \& Fusaroli (2020)의 메타연구와 Guranski \& Podemski(2015)에서도 우반구 손상환자의 음도가 상대적으로 단조롭다고 하였다.

이와 같이 문장전체 음도변이와 관련된 연구들에서는 우반 구가 지배적이라는 연구가 다수를 이루고 있다. 그러나 Behrens (1987, 1988)의 경우 낱말만을 대상으로 했을 때는 우반구 손상 환자와 정상화자의 차이가 없다고 하였으며 Gandour et al.(2004) 은 통사, 의미론적 관점과 긴밀한 성조 이해 및 처리(processing) 
는 좌반구 우세로 보인다고 했다. 한국어 데이터를 사용한 Lee (2010)에서는 장단에 의해서 변별되는 단음절 낱말의 최대 음도 위치와 관련하여 정상화자와 우반구손상 환자는 최대음도값이 형성되는 위치가 비슷하였으나 좌반구손상 환자는 이질적이라 는 보고를 하였다. 이상의 내용들은 의미와 문법성 처리가 관여 되는 음도 산출의 경우 좌반구손상 환자가 어려움을 겪는다는 내용으로 정리될 수 있으며 본 연구에서 살펴본 결과와 그 맥을 같이 하고 있다.

위에서 살펴본 내용으로 다음과 같은 부분이 주의 깊게 고려 될 필요가 있다. 많은 연구들에서 강조하고 있고 집단 간 차이 를 보여주는 가장 뚜렷한 유의변수로 지목하는 음도 변수는 문 장 전역 변수와 지역 변수로 나누어서 살펴보아야 한다는 점이 다. 통사.의미론적으로 상당한 처리가 요구되는 문장의 경우 문 장의 특정 부분과 관여되는 지역적(local) 음도 변수는 좌반구손 상 환자가 적절하게 목표값을 산출하지 못한다는 결론을 얻을 수 있다.

강도 음향변수에서 통계적으로 유의하게 작용한 변수는 강 도 표준편차(senIntDev)였다. 예-아니오 의문문에서 우반구 손 상 환자 집단이 유의하게 작게 나타났다. 유의확률 $90 \%$ 유사 유 의도 수준에서는 유의 음향변수가 4 가지 관찰되었다. 문장 강 도 표준편차(senIntDev)는 의문사 의문문에서 우반구손상 환자 의 편차가 작게 나타났고, 문장 강도 범위(senIntRange)는 의문 사 의문문에서 우반구손상 환자의 강도 범위가 작게 나타났다. 그리고 문장 정규화된 강도 최댓값(senNorIntMax)의 경우도 예아니오 의문문에서 우반구손상 화자가 낮게 나타났다. 문장 전 체를 대상으로 하는 전반 변수에서 우반구 손상 화자가 다른 집 단에 비해 적절한 운율적 특징을 보여주지 못하는 또 다른 방증 이라 할 수 있다. 그리고 첫 낱말 정규화된 최댓값(initial_word NorIntMax)은 의문사 의문문에서 정상 화자에 비해 좌반구손상 환자와 우반구 손상 환자가 모두 약하게 나타났다. Guranski \& Podemski(2015)에서도 ‘화남' 정서의 표현과 관련하여 우반구 손상화자의 강도값이 정상화자보다 낮았으며 Weed \& Fusaroli (2020)의 관찰에서도 적어도 표면적으로는 우반구 화자의 강도 변이가 적었다고 하였다. 이러한 언급들 모두 현 논문에서 기술 한 전반 변수로서의 강도 변수가 보이는 특징을 공유한다고 말 할 수 있다.

산출된 억양의 문형별 자연성(naturalness)에 대한 청지각 평 가 결과, 세 가지 문형 모두 정상화자에 비해 뇌졸중 환자에서 ‘부자연스럽다'의 결과가 크게 나타났다. 의문사 의문문의 경우 는 좌반구손상 환자의 평균점수가 다른 두 집단과 비교하여 통 계적으로 유의하게 낮게 나타났다. 이에 비해 예-아니오와 선택 의문문의 경우 두 집단 모두 정상화자에 비해 유의하게 낮은 평 가를 받긴 했으나 뇌졸중 환자 두 집단 간 유의한 차이가 관찰 되지 않았다.

결과를 종합해보면, 문법적 대뇌처리가 동반되는 문장의 경 우 음도와 발화속도 변수들은 좌반구 손상 환자가 우반구손상 환자보다 정상 패턴에서 멀어져 있음을 알려준다. 또한 예-아니 오 의문문과 선택 의문문보다 의문사 의문문에서 이 같은 경향
이 더욱 두드러짐을 알 수 있다. 음도와 발화속도 변수는, 한국 어 사용자의 의문사 사용에 있어서 어휘-의미론적, 구문론적 정 보와 같은 언어학적으로 관련 있는 대뇌 운율 처리의 경우 우반 구 보다 좌반구에서 우세하다는 선행 연구 결과를(Kreitewolf et al., 2014; Meyer et al., 2002; Shuai \& Gong, 2014) 지지한다. 강도 관련 변수는 문장 전체에 걸친 강도 변이와 같은 전역변수에서 우반구손상 환자의 변이가 작게 나타난데 비해 지역변수에서 는 좌반구손상 환자와 우반구손상 환자 모두 정상 집단과 유의 한 차이를 보였다. 강도의 경우는 지역변수의 경우만 위에서 언 급한 음도와 발화속도 변수의 패턴을 어느 정도 보인다고 정리 할 수 있다.

이 연구의 의의는 텍스트에서 형태상의 차이가 없고, 발화에 서 음향학적 특성으로만 구분되는, 즉, 질문의 의도를 파악하기 위해 운율 정보가 주요 요소로 활용되는 한국어 의문문(의문사 의문문, 예-아니오 의문문, 선택 의문문)의 특성을 좌반구, 우반 구 뇌졸중 환자 모두에 대해 문장 전반 운율변수와 국소적 운율 변수 모두를 활용하여 살펴본 것이다. 연구의 제한점은 다음과 같다. 첫째, 대상자 수가 뇌졸중 환자 14 명(좌반구 손상 7 명, 우 반구 손상 7명)과 정상화자 9명으로 정규 분포를 형성하기에 적 은 데이터 수였다. 검정력을 좀 더 높이기 위해 많은 대상자를 모집한 후속 연구가 필요하다. 둘째, 대조군인 정상 화자의 발 화 데이터는 거주 지역에 따라 운율 특성에 영향을 줄 수 있으 므로 조건을 통제하기 위해 전북지역권 화자 대상으로 수집하 였지만, 표준어 화자의 운율특성과는 다르다는 것을 전제해야 한다. 셋째, 대개의 피험자를 중대뇌동맥과 기저핵 손상 뇌졸중 환자집단에서 구했는데 피험자들이 운율 문제뿐만 아니라 관 찰되기 어려운 기저의 언어 문제까지 있을 개연성이 있다. 최대 한 언어문제가 없는 환자를 고르긴 했으나 기저에 숨어있어 발 견되기 어려운 언어문제까지 충분히 고려했다고 볼 수는 없다.

후속 연구에 대한 제언은 다음과 같다. 이 연구는 운율실현이 까다로운 의문문 유형들을 대상으로 하였다. 즉 처음부터 좌반 구 언어영역의 처리가 개입될 것으로 생각되는 자료들을 연구 대상으로 삼은 것이다. 이는 기존의 연구가 이러한 문법적 문장 들을 잘 다루지 않은 까닭에 언어적 운율의 주 처리 반구가 어 디인지를 좀 더 명확히 하고자 한 까닭이다. 그러나 정서운율 (기쁨, 슬픔과 같은)을 산출해낼 수 있는 실험설계는 아니었다. 좌반구, 우반구 손상 환자군 모두를 대상으로 기쁨, 화남, 슬픔 등 의 정서를 산출해낼 수 있는 한국어 대상 연구가 필요해 보인다.

\section{References}

Balan, A., \& Gandour, J. (1999). Effect of sentence length on the production of linguistic stress by left- and right-hemispheredamaged patients. Brain and Language, 67(2), 73-94.

Behrens, S. J. (1987). The role of the right hemisphere in the production of linguistic prosody. In J. Ryalls (Ed.), Phonetic approaches to speech production in aphasia and related disorders (pp. 81-92). San Diego, CA: College Hill Press. 
Behrens, S. J. (1988). The role of the right hemisphere in theproduction of linguistic stress. Brain and Language, 33(1), 104-127.

Behrens, S. J. (1989). Characterizing sentence intonation in a right hemisphere-damaged population. Brain and Language, 37(2), 181-200.

Belyk, M., \& Brown, S. (2014). Perception of affective and linguistic prosody: An ALE meta-analysis of neuroimaging studies. Social Cognitive and Affective Neuroscience, 9(9), 1395-1403.

Blonder, L. X., Bowers, D., \& Heilman, K. M. (1991). The role of the right hemisphere in emotional communication. Brain, 114(3), 1115-1127.

Boersma, P., \& Weenink, D. (2019). Praat: Doing phonetics by computer (version 6.0.48) [Computer program]. http://www.praat. org/

Bowers, D., Coslett, H. B., Bauer, R. M., Speedie, L. J., \& Heilman, K. M. (1987). Comprehension of emotional prosody following unilateral hemispheric lesions: Processing defect versus distraction defect. Neuropsychologia, 25(2), 317-328.

Ehlers, L., \& Dalby, M. (1987). Appreciation of emotional expressions in the visual and auditory modality in normal and brain-damaged patients. Acta Neurologica Scandinavica, 76(4), 251-256.

Friederici, A. D., \& Alter, K. (2004). Lateralization of auditory language functions: A dynamic dual pathway model. Brain and Language, 89(2), 267-276.

Gandour, J., Dzemidzic, M., Wong, D., Lowe, M., Tong, Y., Hsieh, L., Satthamnuwong, N., \& Lurito, J. (2003). Temporal integration of speech prosody is shaped by language experience: An fMRI study. Brain and Language, 84(3), 318-336.

Guranski, K., \& Podemski, R. (2015). Emotional prosody expression in acoustic analysis in patients with right hemisphere ischemic stroke. Neurol Neurochir Pol, 49(2), 113-120.

Heilman, K. M., Bowers, D., Speedie, L., \& Coslett, H. B. (1984). Comprehension of affective and nonaffective prosody. Neurology, 34(7), 917-921.

Heilman, K. M., Scholes, R., \& Watson, R. T. (1975). Auditory affective agnosia. Disturbed comprehension of affective speech. Journal of Neurology, Neurosurgery and Psychiatry, 38(1), 69-72.

Jung, K. S., \& Seong, C. J. (2007). A comparative study of the prosodic features between autism spectrum disorder and normal children in Korean read sentence. Communication Sciences \& Disorders, 12(4), 625-642.

Kang, S. K., Park, E. S., \& Kang, E. H. (2005). A study of speech therapy program development for patients after a stroke. Communication Disorders, 28(2), 45-57.

Kim, J., \& Seong, C. (2014). The prosodic characteristics of preschool age children-related adults. Phonetics and Speech Sciences, $6(3), 23-32$.
Kim, M. R., Shin, D. H., Choe, J. W., \& Kim, K. H. (2000). Pitch patterns of interrogative sentences in relation to the focus. Speech Sciences, 7(4), 203-217.

Kreitewolf, J., Friederici, A. D., \& von Kriegstein, K. (2014). Hemispheric lateralization of linguistic prosody recognition in comparison to speech and speaker recognition. NeuroImage, 102, 332-344.

Lee, J. M., \& Kwon, D. H. (2005). A study on the development of 2-4 aged childrens comprehension of wh-question. Journal of Speech-Language \& Hearing Disorders, 14(1), 185-204.

Lee, M. S. (2010). A study of the prosodic characteristics of homographs with context cues by subjects with right and left hemisphere damage. Phonetics and Speech Sciences, 2(1), 13-21.

Lee, Y., Kim, H. T., \& Kim, J. (2010). The effect of perceptual training on the reliability of voice quality evaluation. Communication Sciences \& Disorders, 15(4), 526-536.

Lin, R. Z., \& Marsh, E. B. (2021). Abnormal singing can identify patients with right hemisphere cortical strokes at risk for impaired prosody. Medicine, 100(23), e26280.

Meyer, M., Alter, K., Friederici, A. D., Lohmann, G., \& von Cramon, D. V. (2002). FMRI reveals brain regions mediating slow prosodic modulations in spoken sentences. Human Brain Mapping, 17(2), 73-88.

Miller, J., \& Schwanenflugel, P. J. (2006). Prosody of syntactically complex sentences in the oral reading of young children. Journal of Educational Psychology, 98(4), 839-843.

Myers, P. S. (1999). Right hemisphere damage: Disorders of communication and cognition. San Diego, CA: Singular.

Noh, H. M., Kang, E. Y., \& Kim, H. G. (2016). The study of spectral times in patients with cerebrovascular accident focus on basal ganglia intracerebral hemorrhage and middle cerebral artery infarction patients. Proceedings of the Journal of SpeechLanguage \& Hearing Disorders (pp. 220-224). Gwangju, Korea.

Ouellette, G. P., \& Baum, S. R. (1994). Acoustic analysis of prosodic cues in left- and right-hemisphere-damaged patients. Aphasiology, 8(3), 257-283.

Perry, D. W., Zatorre, R. J., Petrides, M., Alivisatos, B., Meyer, E., \& Evans, A. C. (1999). Localization of cerebral activity during simple singing. Neuroreport, 10(18), 3979-3984.

Poldrack, R. A., Temple, E., Protopapas, A., Nagarajan, S., Tallal, P., Merzenich, M., \& Gabrieli, J. D. E. (2001). Relations between the neural bases of dynamic auditory processing and phonological processing: Evidence from fMRI. Journal of Cognitive Neuroscience, 13(5), 687-697.

Ross, E. D. (1981). The aprosodias. Functional-anatomic organization of the affective components of language in the right hemisphere. Archives of Neurology, 38(9), 561-569.

Seo, I. H., \& Seong, C. J. (2012). The prosodic characteristics of 
dysarthria with respect to speech rate and intonation slope. Communication Sciences \& Disorders, 17(3), 390-402.

Seong, C., Gim, C., \& Kwon, O. (2019). kPhonetica (version 2.08) [Computer program]. https://blog.naver.com/cj_seong/220265205693 Shuai, L., \& Gong, T. (2014). Temporal relation between top-down and bottom-up processing in lexical tone perception. Frontiers in Behavioral Neuroscience, 8, 97.

Tucker, D. M., Watson, R. T., \& Heilman, K. M. (1977). Discrimination and evocation of affectively intoned speech in patients with right parietal disease. Neurology, 27(10), 947-950.

Weed, E., \& Fusaroli, R. (2020). Acoustic measures of prosody in right-hemisphere damage: A systematic review and meta-analysis. Journal of Speech, Language, and Hearing Research, 63(6), 1762-1775.

Witteman, J., van Ijzendoorn, M. H., van de Velde, D. J., van Heuven, V. J. J. P., \& Schiller, N. O. (2011). The nature of hemispheric specialization for linguistic and emotional prosodic perception: A meta-analysis of the lesion literature. Neuropsychologia, 49(13), 3722-3738.

Yu, Y., Park, S., \& Seong, C. (2020). Comparison of prosodic characteristics according to the question types in patients with left hemisphere damaged and right hemisphere damaged. Proceedings of the 2020 Conference of the Korean Society of Speech Sciences ( $\mathrm{p}$. 48). Seoul, Korea.

Yu, Y. M. (2020). Linguistic prosody characteristics of stroke speakers (Master's thesis). Chungnam National University, Daejeon, Korea.

\section{- 유영미 (Youngmi Yu)}

충남대학교 언어병리학과 석사

대전 유성구 대학로 99

Tel: 042-821-6391

Email: duda17178@hanmail.net

관심분야: 신경언어장애, 운율분석

- 성철재 (Cheoljae Seong) 교신저자

충남대학교 언어학과 교수

대전 유성구 대학로 99

Tel: 042-821-6395

Email: cjseong49@gmail.com

관심분야: 분절음 및 운율분석 


\title{
좌반구 손상과 우반구 손상 뇌졸중 환자의 의문문 유형에 따른 운율 특성 비교*
}

\author{
유 영 미 ${ }^{1} \cdot$ 성 철 재 ${ }^{2}$ \\ 1충남대학교 언어병리학과, ${ }^{2}$ 충남대학교 언어학과
}

\section{국문초록}

의사소통에 중요한 역할을 하는 운율은 기능에 따라 언어적 운율과 정서적 운율로 구분한다. 대뇌 편재화 관점에 서 정서적 운율 처리는 우반구가 주로 담당한다는 결과가 일반론적으로 받아들여지지만, 언어적 운율에 대한 연구 들은, 연구간의 방법적인 차이로 인해 결과가 상이하게 나타난다. 본 연구는 정상 화자 9명과 뇌졸중 환자 14명(좌 반구 손상 7명, 우반구 손상 7명)의 세 집단을 대상으로 대뇌 편재화의 관점에서 언어적 운율 특성을 살펴보기 위해 세 가지 형태 의문문(의문사 의문문, 예-아니오 의문문, 선택 의문문)에서의 발화속도, 지속시간, 음도, 강도와 관련 된 운율 특징을 청지각 평가와 함께 살펴보았다. 연구결과, 통계적으로 유의한 주요변수들이 좌반구 손상 환자의 자료에서 결함을 보였으며, 예-아니오 의문문과 선택 의문문보다 의문사 의문문에서 더욱 두드러졌다. 이러한 경 향은 특히 음도와 발화속도 관련 변수들에서 두드러졌다. 본 연구의 결과는 한국어 사용자의 의문사 사용에 있어 서 어휘-의미론적, 구문론적 정보와 같은 언어학적으로 관련 있는 운율 처리의 경우 우반구보다 좌반구에서 대체 로 우세하다는 점을 방증한다.

핵심어: 뇌졸중, 언어적 운율, 의문문, 음향분석

\section{참고문헌}

강수균, 박은실, 강은희(2005). 뇌졸중자의 언어치료 프로그램 개 발. 난청과 언어장애, 28(2), 45-57.

김미란, 신동현, 최재웅, 김기호(2000). 초점과 관련된 의문문 억 양 패턴 실험. 음성과학, 7(4), 203-217.

김지원, 성철재(2014). 학령전기아동 관련 성인의 운율 특성. 말 소리와 음성과학, 6(3), 23-32.

노혜미, 강은영, 김현기(2016). 뇌졸중 환자 음성언어의 Spectral times 연구: 대뇌 기저핵부 출혈 환자와 중대뇌동맥 뇌경색 환 자를 비교 대상으로. 한국언어치료학회 2016년도 제20회 학 술발표대회 논문집 (pp. 220-224).

서인효, 성철재(2012). 마비말화자와 정상화자의 양자택일의문 문 운율비교. 언어청각장애연구, 17(3), 390-402.

유영미(2020). 뇌졸중 화자의 언어적 운율 특성. 충남대학교 석사 학위논문.

유영미, 박소현, 성철재(2020). 좌반구 손상과 우반구 손상 뇌졸 중 환자의 의문문 유형에 따른 운율 특성 비교. 2020 한국음성 학회 학술대회 발표논문집(p. 48).
이명순(2010). 문맥 내에서 좌우반구 손상자의 동음어에 대한 운 율 산출 비 교. 말소리와 음성과학, 2(1), 13-21.

이영아, 김형태, 김재옥(2010). 청지각적 음성평가 훈련이 음성평 가 신뢰도에 미치는 효과. 언어청각장애연구, 15(4), 526-536.

이정미, 권도하(2005). 2 4세 아동의 의문사 이해에 관한 연구. 언 어치료학, 14(1), 185-204.

정금수, 성철재(2007). 자폐범주성 장애아동과 정상아동의 문장 읽기에서의 운율 특성 비교. 언어청각장애연구, $12(4), 625-642$.

* 이 논문은 제 1 저자의 2020 석사학위 내용과 2020 년 한국음성학회 가을 학술대회 발표논문의 일부를 수정, 보완한 것입니다. 